\title{
The Exploration of Bacteria Having Bio control Ability against the Golden Cyst Nematode (Globodera rostochiensis) in Potato Cultivation Lands
}

\author{
Irianti Kurniasari', Siwi Indarti ${ }^{2}$ and Donny Widianto ${ }^{3 *}$ \\ 'Department of Biotechnology, Sustainable Agricultural Extension Program, Politeknik Pembangunan Pertanian \\ Malang, J. Dr. Cipto 144A, Bedali, Lawang, Malang, 65200, Indonesia; iriantikurniasari@polbangtanmalang.ac.id \\ 2Department of Plant Protection, Faculty of Agriculture, Universitas Gadjah Mada, J. Flora Bulaksumur, \\ Yogyakarta, 55281, Indonesia; indarti@faperta.ugm.ac.id \\ ${ }^{3}$ Research Center for Biotechnology, Universitas Gadjah Mada, Jl. Teknika Utara, Barek, \\ Yogyakarta, 55281, Indonesia; donny@ugm.ac.id
}

\begin{abstract}
Objective: To findout the existence and diversity of bacteria having bio control ability against Globodera rostochiensis from six different location of potato cultivation lands in Wonosobo and Banjarnegara Indonesia. Methods: The bacteria and cyst of $G$. rostochiensis were isolated and Walkey-Black titration method were used to analyze the C-organic content from each location. The bio control ability of bacterial isolates was tested against cysts and eggs of G. rostochiensis followed by PCR-RAPD with two universal primers for molecular characters differentiation. Simpson's and Shannon's index methods were used to measure the diversity of bacteria. Findings: 45 bacterial strains were isolated. The bio control ability test showed that all strains have bio control ability against cysts and eggs of $G$. rostochiensis. Moreover, the PCR-RAPD showed that 33 isolates were categorized as different species. The high and medium diversity indexes indicated that the soil parasitic bacteria against $G$. rostochiensis have already been evolved diversely in potato cultivation lands. Novelty: The bacterial isolates that having dominant bio control ability against the golden cyst nematode from each location would be of commercial inoculant bionematicide.
\end{abstract}

Keywords: Bacteria, Biological Control, Golden Cyst Nematode, G. rostochiensis, Potato

\section{Introduction}

Golden cyst nematode (GCN), Globodera rostochiensis (Wollenweber) is a plant parasitic nematode that caused a significant economic loss to the potato production. The GCN is difficult to be controlled because they live in soil. Moreover, the egg is protected by the cyst from chemical and biological stresses found in soil and can remains dormant for more than 20 years in the absence of host plants. Also, GCN has high reproducibility with 200-500 eggs per generation $\frac{1,2}{2}$. Since it was reported to cause economic losses for the first time in 2003 in Batu, East Java ${ }^{3}$, the number of the infested potato cultivations has increased continuously, as well as their population.

Based on the observation in Central Java, Wonosobo and Banjarnegara regencies had the largest potato cultivation lands infested with $G$. rostochiensis and the cyst population was 242 per 100 g soil ${ }^{4}$. Furthermore, during the absence of plants rotation, the plant damages may reach up to $100 \%$.

Bacteria are one of the major groups of microorganisms that can be used as effective biological control agents against the GCN. According to the previous report ${ }^{5}$, the soil bacteria that can reduce the population of $G$. rostochiensis cysts and eggs are parasitic bacteria. The continuous and abundant availability of G. rostochiensis cysts and eggs may increase the number and species of their natural enemies including parasitic bacteria. Thus, several years after first detection of G. rostochiensis in Indonesia, it can be expected that the parasitic bacteria against G. rostochiensis and other pneumatophores bacteria have been evolved and varied in Indonesian

*Author for correspondence 
potato cultivation lands. The objective of this study was to elucidate the existence and diversity of parasitic bacteria against G. rostochiensis.

\section{Materials and Methods}

\subsection{Soil Sampling}

Stratified random sampling was performed in this research. Rhizospheric soils of healthy and nematode infected potato plants were taken from a depth of $10-30 \mathrm{~cm}$ at six different sites in Wonosobo and Banjarnegara Regency, Central Java as follows: Karang Bakal, Karang Tengah, Telaga Merdada, Pathak Banteng, Dieng Kulon, and Sumberejo. The C-organic content was analyzed using a modified WalkleyBlack titration method ${ }^{6}$.

\subsection{Isolation and Purification of Bacteria}

The pour plate method was used for bacteria isolation? Nutrient and soil extract agar media were used to grow the bacterial isolates. Purification of single colonies were carried out based on the different morphology by streaking repeatedly on new agar medium in the petri dish until the colony was uniform.

\subsection{Extraction of G. rostochiensis from the Soil}

The G. rostochiensis cysts were extracted from $20 \mathrm{~g}$ drained soil using Fenwick flotation method ${ }^{8}$.

\subsection{In-Vitro Pathogenicity test for Bacterial Isolates Against Cysts and Eggs of G. rostochiensis}

The in-vitro pathogenicity test for bacterial isolates against cysts and eggs of G. rostochiensis were carried out according to a standard method ${ }^{9}$ with slight modification. Ten of the cysts were added into the multi well plate followed by the addition of bacterial cells suspension. The pathogenicity test for eggs of G. rostochiensis was done as follows: eggs suspension that has been counted was added into the multi well plate containing the same volume of bacterial cells suspension.

Both pathogenicity tests for G. rostochiensis cyst and eggs were made by 3 replicates. For control, the bacterial suspension was replaced with sterile aquadest. They were all incubated at room temperature. The number of damaged cysts and eggs were counted after 5 days of incubation.

\subsection{Bacterial Isolates Differentiation}

Bacterial isolates were differentiated based on the morphological and molecular characters. Cell and colony morphology were observed with an olympus SZX12 (Japan) stereo microscope. Ribosomal region analysis was conducted by isolating the bacterial genomic DNA using mini prep methods and then amplifying the DNA using a Polymerase Chain Reaction (PCR) (Mastercycler Personal, Eppendorf, Germany) with universal primers 1400 F (5'-TGYACACACCGCCCGT-3') and 23sR (5'-GGGTTBCCCCATTCRG) (Invitrogen, California). The amplified DNA was visualized by $8 \%$ Polyacrylamide Gel Electrophoresis (PAGE). The gel was stained with $0.1 \%(\mathrm{w} / \mathrm{v})$ silver nitrate $\mathrm{e}^{10,11}$.

\subsection{Diversity Index Analysis}

The diversity of bacterial isolates was determined using Simpson's and Shannon's diversity indexes $\frac{12,13}{}$.

$$
\begin{aligned}
& \mathrm{D}=\sum_{i=1}^{s} P i^{2} \\
& H^{\prime}=-\sum_{i=1}^{s} P i \ln P i
\end{aligned}
$$

Table 1. The value and description of diversity index

\begin{tabular}{|l|l|l|}
\hline \multicolumn{1}{|c|}{$\begin{array}{c}\text { Diversity } \\
\text { Index }\end{array}$} & \multicolumn{2}{|c|}{ Description } \\
\hline $\begin{array}{l}\text { Shannon's } \\
\text { index }\end{array}$ & $\mathrm{H}<1$ & $\begin{array}{l}\text { Low diversity (there are few species } \\
\text { in the sample) }\end{array}$ \\
\cline { 2 - 3 } & $1<\mathrm{H}<3$ & $\begin{array}{l}\text { Middle diversity (there is a medium } \\
\text { number of species in the sample) }\end{array}$ \\
\cline { 2 - 4 } & $\mathrm{H}>3$ & $\begin{array}{l}\text { High diversity (all species are } \\
\text { represented by the same number of } \\
\text { individuals) }\end{array}$ \\
\hline $\begin{array}{l}\text { Simpson's } \\
\text { index }\end{array}$ & $\mathrm{D}=0$ & Community with infinite diversity \\
\cline { 2 - 3 } & $\mathrm{D}=1$ & Community with no diversity \\
\hline
\end{tabular}

Remarks: $\mathrm{D}=$ Simpson's index, $\mathrm{H}^{\prime}=$ Shannon's index, $P i=$ the proportion of individuals found in species, $i=$ species, $s=$ number of species, and $\ln =$ the natural $\log$.

\section{Results and Discussion}

\subsection{C-Organic Content and Cyst Number of Sampled Soil}

The results of $\mathrm{C}$-organic analysis showed that all of the sampling sites were categorized as having high C-organic content according to the criteria published by the Soil 
Research Center (formerly called Puslitanak) (Table 2). The high C-organic content in all sampling sites were due to chicken manures applications during the planting season. The chicken manure may improve soil structure and the availability of nutrition for potato plants as the G. rostochiensis host $\frac{14,15}{15}$. Thus, the potato plants grown in soil having high C-organic content may support the growth of G. rostochiensis better than those in the lower ones. This phenomenon can be inferred from Table 3, which shows the cyst number of G. rostochiensis was found to be higher in the soil having high $\mathrm{C}$-organic content. Root diffusates that are released by potato plants which contain sugars, amino acids, protein, and other organic acids, could increase the population of cyst G. rostochiensis with stimulating $60-80 \%$ of the hatching of cyst G. rostochiensis $\frac{1,16}{}$. Therefore, the cyst number of $G$. rostochiensis was also found to be higher in the rhizosphere of infected potato plants compared to the healthy potato plants (Table 3 ).

Table 2. Soil C-organic content of the sampling sites

\begin{tabular}{|c|c|}
\hline Location & C-Organic (\%) \\
\hline $\mathrm{KB}$ & 6.13 \\
\hline $\mathrm{KT}$ & 6.76 \\
\hline $\mathrm{TM}$ & 6.23 \\
\hline $\mathrm{PB}$ & 5.23 \\
\hline $\mathrm{DK}$ & 5.97 \\
\hline $\mathrm{SRJ}$ & 5.85 \\
\hline
\end{tabular}

Remarks: $\mathrm{KB}=$ Karang Bakal, $\mathrm{KT}=$ Karang Tengah, $\mathrm{TM}=$ Telaga Merdada, $\mathrm{PB}=$ Pathak Banteng, $\mathrm{DK}=$ Dieng Kulon, SRJ $=$ Sumberejo.
Table 3. The cyst number of G. rostochiensis in rhizospheric healthy and infected potato plants

\begin{tabular}{|c|c|c|}
\hline Location & $\begin{array}{c}\text { Rhizospheric } \\
\text { healthy plant }\end{array}$ & $\begin{array}{c}\text { Rhizospheric } \\
\text { infected plant }\end{array}$ \\
\hline KB & $10.7^{\mathrm{f}}$ & $123.3^{\mathrm{a}}$ \\
\hline KT & $10.3^{\mathrm{f}}$ & $114.3^{\mathrm{b}}$ \\
\hline TM & $10.7^{\mathrm{f}}$ & $68.7^{\mathrm{c}}$ \\
\hline PB & $10.7^{\mathrm{f}}$ & $50.7^{\mathrm{d}}$ \\
\hline DK & $12.0^{\mathrm{f}}$ & $36.0^{\mathrm{e}}$ \\
\hline SRJ & $10.3^{\mathrm{f}}$ & $16.0^{\mathrm{f}}$ \\
\hline
\end{tabular}

Remarks: Average of three replications of the cyst calculation per $20 \mathrm{~g}$ of soil. Numbers followed by the same letter are not significantly different at 95\% test level, $\mathrm{KB}=$ Karang Bakal, $\mathrm{KT}=$ Karang Tengah, $\mathrm{TM}=$ Telaga Merdada, $\mathrm{PB}=$ Pathak Banteng, $\mathrm{DK}=$ Dieng Kulon, SRJ = Sumberejo.

\subsection{Total Bacterial Population}

The total number of rhizospheric soil bacteria of healthy and infected potato plants was counted on two different agar media. The results showed that the bacteria number in the rhizosphere of infected potato plants is higher than in the rhizosphere of healthy potato plants on both media as shown in Table 4. It is likely that complex interactions occur between soil bacteria, golden cyst nematodes, and host plants to affect the populations of bacteria as well as the population of the golden cyst nematode. The population dynamics of both the bacteria and GCN depend on the carbon cycle of the food chains in the soil ${ }^{17}$. Indirectly, the presence of carbon sources in soil could increase the population of the bacteria and GCN.

Table 4. Bacterial population of rhizospheric healthy and infected potato plants

\begin{tabular}{|c|c|c|c|c|}
\hline \multirow{2}{*}{ Location } & \multicolumn{3}{|c|}{ NA (Nutrient Agar) } & \multicolumn{2}{c|}{ SE (Soil Extract) } \\
\cline { 2 - 5 } & $\begin{array}{c}\text { Rhizospheric healthy } \\
\text { plant }\end{array}$ & $\begin{array}{c}\text { Rhizospheric infected } \\
\text { plant }\end{array}$ & Rhizospheric healthy plant & Rhizospheric infected plant \\
\hline KB & 5.60 & 5.90 & 6.70 & 6.80 \\
\hline KT & 5.60 & 5.90 & 4.80 & 6.08 \\
\hline TM & 4.80 & 6.00 & 5.70 & 6.10 \\
\hline PB & 5.80 & 6.04 & 5.40 & 5.90 \\
\hline DK & 5.50 & 5.70 & 6.05 & 6.05 \\
\hline SRJ & 5.60 & 6.00 & 4.90 & 4.70 \\
\hline
\end{tabular}

Remarks: Total population of bacteria in Log colony forming unit (Log cfu), KB = Karang Bakal, KT = Karang Tengah, TM = Telaga Merdada, PB = Pathak Banteng, DK = Dieng Kulon, SRJ = Sumberejo 
Moreover, a higher cyst number of G. rostochiensis in the rhizosphere of infected potato plants may cause a higher number of soil bacteria since the cysts can be used as the carbon source, especially by parasitic bacteria ${ }^{18}$.

\subsection{Parasitic Bacterial Isolates}

The 45 different isolates obtained herein were observed to be parasitic against both the cyst and egg of G. rostochiensis as shown in Table 5. The parasitic bacteria attacked the outer layer of the cysts and eggs of G. rostochiensis (Figure 1). It is known that the eggshell and cyst wall of the golden cyst nematode consists of protein, chitin, and lipid $\frac{(19,20)}{}$. These can be used by parasitic bacteria as energy and carbon sources, therefore, the soil bacterial number was higher in the soil with a higher cyst number (Table 3 and 4).
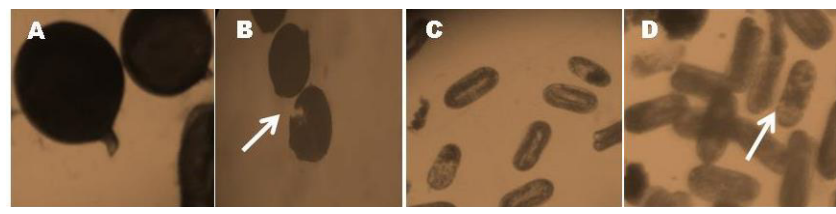

Figure 1. The cysts and eggs of G. Rostochiensis. (A) healthy cysts $(M=10 \times 40)$, (B) cyst treated with bacterial isolates $(M=10 \times 20)$, (C) healthy eggs $(\mathrm{M}=10 \times 10),(\mathrm{D})$ eggs treated with bacterial isolates $(\mathrm{M}=10 \times 20)$.

Table 5. Parasitic bacterial isolates isolated from the different locations, media and rhizospheric soil sampling

\begin{tabular}{|c|c|c|c|c|c|c|c|}
\hline \multicolumn{3}{|c|}{ Source of isolates } & \multicolumn{2}{|c|}{ Categorized as } & \multirow{2}{*}{$\begin{array}{l}\Sigma \text { micro-bial } \\
\text { colonies/part }\end{array}$} & \multirow{2}{*}{$\begin{array}{c}\Sigma \text { micro-bial } \\
\text { colonies/group }\end{array}$} & \\
\hline Location & Medium & Rhizo-spheric & Para-sitic & Non-para-sitic & & & \\
\hline \multirow[t]{4}{*}{$\mathrm{KB}$} & \multirow[t]{2}{*}{ NA } & Infected & 2 & 0 & 2 & \multirow[t]{2}{*}{6} & \multirow[t]{4}{*}{10} \\
\hline & & Healthy & 4 & 0 & 4 & & \\
\hline & \multirow[t]{2}{*}{ SE } & Infected & 1 & 0 & 1 & \multirow[t]{2}{*}{4} & \\
\hline & & Healthy & 3 & 0 & 3 & & \\
\hline \multirow[t]{4}{*}{$\mathrm{KT}$} & \multirow[t]{2}{*}{ NA } & Infected & 4 & 0 & 4 & \multirow[t]{2}{*}{7} & \multirow[t]{4}{*}{11} \\
\hline & & Healthy & 3 & 0 & 3 & & \\
\hline & \multirow[t]{2}{*}{ SE } & Infected & 2 & 0 & 2 & \multirow[t]{2}{*}{4} & \\
\hline & & Healthy & 2 & 0 & 2 & & \\
\hline \multirow[t]{4}{*}{$\mathrm{TM}$} & \multirow[t]{2}{*}{$\mathrm{NA}$} & Infected & 4 & 0 & 4 & \multirow[t]{2}{*}{8} & \multirow[t]{4}{*}{13} \\
\hline & & Healthy & 4 & 0 & 4 & & \\
\hline & \multirow[t]{2}{*}{$\mathrm{SE}$} & Infected & 5 & 0 & 5 & \multirow[t]{2}{*}{5} & \\
\hline & & Healthy & 0 & 0 & 0 & & \\
\hline \multirow[t]{4}{*}{$\mathrm{PB}$} & \multirow[t]{2}{*}{ NA } & Infected & 0 & 0 & 0 & \multirow[t]{2}{*}{0} & \multirow[t]{4}{*}{4} \\
\hline & & Healthy & 0 & 0 & 0 & & \\
\hline & \multirow[t]{2}{*}{ SE } & Infected & 2 & 0 & 2 & \multirow[t]{2}{*}{4} & \\
\hline & & Healthy & 2 & 0 & 2 & & \\
\hline \multirow[t]{4}{*}{$\mathrm{DK}$} & \multirow[t]{2}{*}{ NA } & Infected & 0 & 0 & 0 & \multirow[t]{2}{*}{0} & \multirow[t]{4}{*}{3} \\
\hline & & Healthy & 0 & 0 & 0 & & \\
\hline & SE & Infected & 2 & 0 & 2 & 3 & \\
\hline & & Healthy & 1 & 0 & 1 & & \\
\hline SRJ & $\mathrm{NA}$ & Infected & 0 & 0 & 0 & 0 & 4 \\
\hline & & Healthy & 0 & 0 & 0 & & \\
\hline & $\mathrm{SE}$ & Infected & 2 & 0 & 2 & 4 & \\
\hline & & Healthy & 2 & 0 & 2 & & \\
\hline$\Sigma$ species & microbes & & 45 & 0 & 45 & & \\
\hline
\end{tabular}

Remarks: $\mathrm{KB}=$ Karang Bakal, KT = Karang Tengah, $\mathrm{TM}=$ Telaga Merdada, $\mathrm{PB}=$ Pathak Banteng, DK= Dieng Kulon, $\mathrm{SRJ}=$ Sumberejo 


\subsection{Bacterial Diversity}

Rep-PCR analyses were done to distinguish among the bacterial isolates. Figure 2 shows the difference among 7 bacterial isolates having relatively high bio control ability against G. rostochiensis. Based on the same analyses for the whole isolates, we calculated the diversity indexes and the results are shown in Table 6 . The calculated diversity was categorized as a medium to high level, implicated that the bacteria which have bio control ability against G. rostochiensis have been diversed in potato cultivation lands.

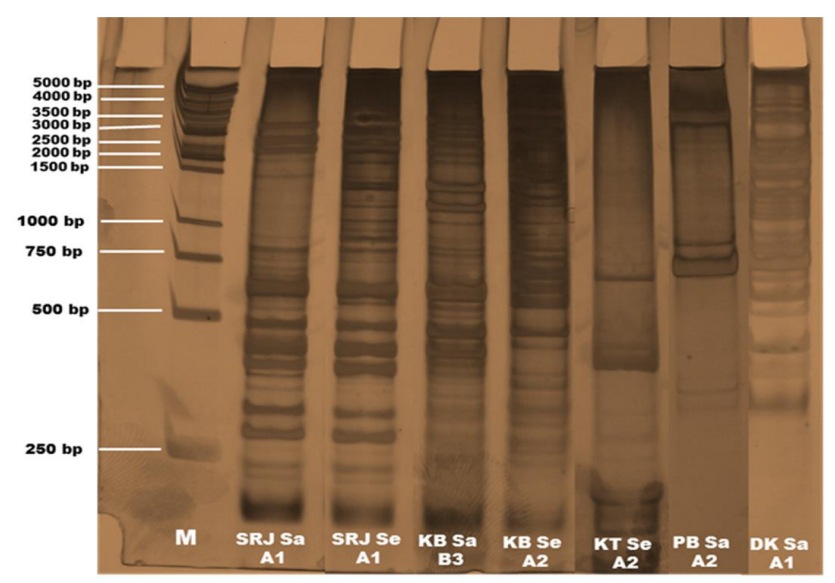

Figure 2. PAGE analysis of bacterial isolates having dominant parasitic ability against $G$. rostochiensis from each location.

$\mathrm{M}=$ Marker, SRJ $=$ Sumberejo, $\mathrm{KB}=$ Karang Bakal, $\mathrm{KT}=$ Karang Tengah, $\mathrm{PB}=$ Pathak Banteng, $\mathrm{DK}=$ Dieng Kulon, $\mathrm{Sa}=$ Infected rhizosphere, $\mathrm{Se}=$ Healthy rhizosphere .

Table 6. Simpson's and Shannon's diversity index of parasitic bacterial isolates

\begin{tabular}{|l|c|c|c|}
\hline \multirow{2}{*}{ Source of isolate } & \multicolumn{2}{|c|}{ Index values } & \multirow{2}{*}{ Criterion } \\
\cline { 2 - 3 } & $\mathbf{D}$ & $\mathbf{H}^{\prime}$ & \\
\hline Location & 0.164 & 3.902 & High \\
\hline Type of medium & 0.219 & 1.566 & Medium \\
\hline Rhizospheric & 0.195 & 1.690 & Medium \\
\hline
\end{tabular}

\section{Conclusions}

The bacteria having bio control ability against G. rostochiensis were varied among the sixth different sites of soil sampling. The diversity of the bacteria was influenced by the soil sampling site, growth medium, and the status of the host plant. All of the bacterial isolates were parasitic. Further research works are needed to find out the mechanism of parasitation and exploitation of the bacteria as bio control agents against G. rostochiensis.

\section{References}

1. Martinez-Beringola ML, Salto T, Vázquez G, Larena I, Melgarejo P, De Cal A. Penicilliumoxalicum reduces the number of cysts and juveniles of potato cyst nematodes, Journal of Applied Microbiology. 2013; 115:199-206. https://doi.org/10.1111/jam.12213.

2. Eves-van den Akker S, Laetsch DR, Thorpe P, Lilley CJ, Danchin EGJ, Da Rocha M, et al. The genome of the yellow potato cyst nematode, Globodera rostochiensis, reveals insights into the basis of parasitism and virulence, Genome Biology. 2016; 17(124):1-23. https://doi.org/10.1186/ s13059-016-0985-1.

3. Indarti S, Rahayu B, Mulyadi, Triman B. First record of potato cyst nematode Globodera rostochiensis in Indonesia, Australasian Plant Pathology. 2004; 33:325-26. https://doi.org/10.1071/AP04018.

4. MulyadiIndarti S, Rahayu B, Triman B. Moleculer and pathotype identification of potato cyst nematodes, J Perlindungan Tanaman Indonesia. 2014; 18(1):17-23.

5. Kerry B. Rhizosphere interaction and the exploitation of microbial agents for the biological control of plant -parasitic nematodes, Annual Review of Phytopathology. 2000; 38:423-41. https://doi.org/10.1146/annurev. phyto.38.1.423.

6. Gelman F, Binstock R, Halicz L. Application of the Walkley - Black titration for the organic carbon quantification in organic rich sedimentary rocks, Fuel. 2012; 96:608-10. https://doi.org/10.1016/j.fuel.2011.12.053.

7. Sanders E. Aseptic laboratory techniques: Plating methods, Journal of Visualized Experiments. 2012; 63-64:1-18. https://doi.org/10.3791/3064.

8. PM 7/119(1) Nematode extraction, EPPO Bulletin. 2013; 43(3). Date accessed: 2013. https://onlinelibrary.wiley.com/ doi/full/10.1111/epp.12077.

9. Bin L, Guan-lin X, Soad A, Coosemans J. Suppression of Meloidogyne javanica by antagonistic and plant growthpromoting rhizobacteria, Journal of Zhejiang University Science. 2005; 6(6):496-501. https://doi.org/10.1631/ jzus.2005.B0496.

10. Current Protocols in Molecular Biology. Date accessed: 2019. https://currentprotocols.onlinelibrary.wiley.com/ journal/19343647/.

11. Rivas R, Velazquez E, Valverde A, Mateos P, Martinez-Molina E. A two primers random amplified polymorphic DNA procedure to obtain polymerase chain reaction, Electrophoresis. 2001; 22:1086-89. https://doi.org/10.1002/1522-2683()22:6<1086::AIDELPS1086>3.0.CO;2-6. 
12. Toana M, Mudjiono G, Karindah S, Abadi A. Diversity of Arthropods on cocoa plantation in three strata of shade tree, AGRIVITA Journal of Agricultural Science. 2014; 36(2):120-27. https://doi.org/10.17503/Agrivita-2014-36-2-p120-127.

13. Tarno H, Septia E, Aini L. Microbial community associated with ambrosia beetle, Euplatypus parallelus on sonokembang, Pterocarpus indicus in Malang, AGRIVITA Journal of Agricultural Science. 2016; 38(3):312-20. https:// doi.org/10.17503/agrivita.v38i3.628.

14. Ohsowski B, Klironomos J, Dunfield K, Hart M. The potential of soil amendments for restoring severely disturbed grasslands, Applied Soil Ecology. 2012; 60:77-83. https://doi.org/10.1016/j.apsoil.2012.02.006.

15. Hong S, Anees M, Kim K. Bio control of Meloidogyne incognita inciting disease in tomato by using a mixed compost inoculated with Paenibacillusehimensis RS820, Bio control Science and Technology. 2013; 23(9):1024-39. https://doi.org/10.1080/09583157.2013.811468.

16. Yang G, Zhou B, Zhang X, Zhang Z, Wu Y. Effects of tomato root exudates on Meloidogyne incognita, PLoS One. 2016; 11(4):1-16. https://doi.org/10.1371/journal.pone.0154675.
17. Costa S, Van der Putten W, Kerry B. Microbial ecology and nematode control in natural ecosystems. In: Biological control of plant parasitic nematodes: Building coherence between microbial ecology and molecular mechanisms; 2011. p. 39-64. https://doi.org/10.1007/978-1-4020-9648-8_2.

18. Tian B, Yang J, Zhang K. Bacteria used in the biological control of plant-parasitic nematodes: Populations, mechanisms of action, and future prospects, FEMS Microbiology Ecology. 2007; 61:197-213. https://doi. org/10.1111/j.1574-6941.2007.00349.x.

19. Perry R, Wharton D, Clarke A. The structure of the eggshell of Globodera rostochiensis (nematoda: Tylenchida), International Journal for Parasitology. 1982; 12(5):481-85. https://doi.org/10.1016/0020-7519(82)90080-7.

20. Clarke AJ. The chemical composition of the cyst wall of the potato cyst-nematode, Heterodera rostochiensis, Biochemical Journal. 1968; 108:221-24. https://doi. org/10.1042/bj1080221. 